hæmoglobin of a 10-week-old human fœetus which Halbrecht and Klibansky identified by means of paper electrophoresis. The "primitive type $P$ " embryonic hæmoglobin described by Allison ${ }^{2}$ and the early embryonic hæmoglobin distinguished through alkali denaturation by Drescher and Künzer ${ }^{1}$ may well be identical with the hæmoglobin of the small foetuses reported here.

The migration pattern of the hæmoglobins of the 15-18-week-old fœetuses differed significantly from the hæmoglobins of the 7-12-week-old group. The mobility of the hæmoglobins of the older group of fœtuses showed but small differences as compared with the hæmoglobin of normal full-term infants.

From the results of this investigation it was thus possible to distinguish a human embryonic hæmoglobin from a group of 7-12-week-old foetuses, which, on paper electrophoresis under the conditions described, showed a mobility definitely slower than that of the hæmoglobin of normal full-term infants. The mobility of the hæmoglobins of the group of 15-18-week-old foetuses did not differ significantly from that of normal full-term infants.

These findings support the view ${ }^{4}$ that the hæmoglobin in the erythrocytes derived from the mesoblastic tissue during early embryonic life is of a different type from the hæmoglobin of hepatic and medullary origin. If this holds true, most of the hæmoglobin of mesoblastic type is replaced by hæmoglobin of hepatic origin in the course of 15-18 weeks of fœetal life.

I am indebted to the Sigrid Jusélius Foundation. for a grant towards the cost of this investigation.

\title{
Harry Zilliacus
}

Department of Obstetrics and Gynæcology I, University Central Hospital, Helsinki.

${ }^{1}$ Drescher, H., and Künzer, W., Klin. Wschr., 32, 92 (1954).

2 Allison, A., Science, 122, 640 (1955).

s Halbrecht, J., and Klibansky, C., Nature, 178, 794 (1956).

" Künzer, W., Nature, 179, 477 (1959).

'Fessas, P., Mastrokalos, N., and Fostiropulus, G., Nature, 183, 31 (1959).

- Vella, F., Nature, 184, 272 (1959).

'Jonxis, J. H. P., in "Abnormal Haemoglobins", 118 (Blackwell Sci. Pub., Oxford, 1959).

${ }^{8}$ Singer, K., Chernoff, A. T., and Singer, L., Blood, 6, 413 (1951).

\section{PATHOLOGY}

\section{Leucocytic Emigration from Inflamed Capillaries}

THE precise manner in which margination and emigration of leucocytes occur in acute inflammation has not beon olucidated despite numerous careful studies with the light microscope. Utilizing electron microseopy we have observed the emigration of leucocytes from capillaries in areas of acute inflammation in dog pancreas. Capillary endothelial cells react to injury by forming intra-lumenal finger-like projections of cytoplasm. These projections insinuate themselves around, and envolop, adjacent leucocytes, and, in this manner, draw the latter into the capillary wall (Fig. 1). This intramural localization of leucocytes is equivalent to 'margination' as seen by light microscopy and would appear to occur by a process similar to that of phagocytosis. The leucocytes are then extruded through the antiluminal border of the endothelial cell where they are separated from the extravascular space only by the basement membrane

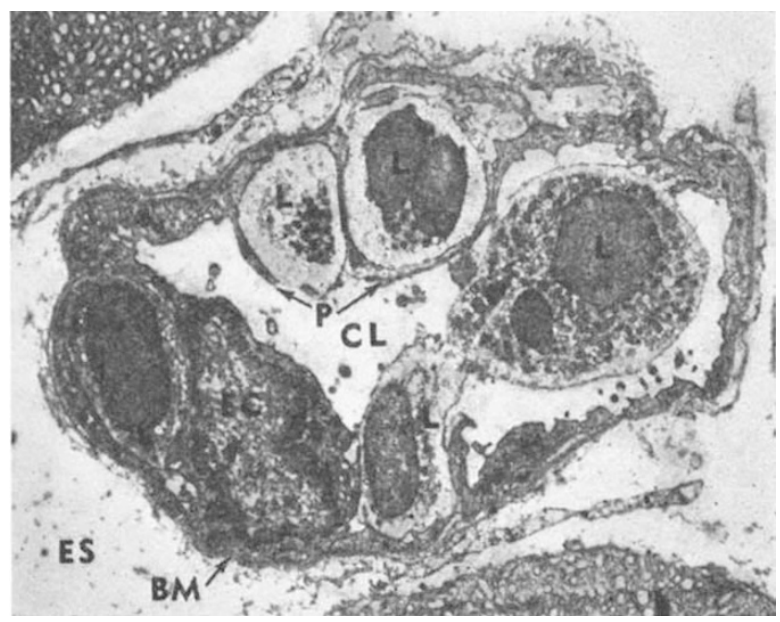

Fig. 1. Electron photomicrograph of an inflamed capillary in processes $(P)$. basement membrane $(B M)$, extravascular space $(E S)$. $(\times c, 4,670)$,

of the endothelial cell. After separation of leucocyte and endothelial cell by as much as $300 \AA$., new basement membrane forms between thern and is continuous with the old. Simultaneously old basement membrane adjacent to the leucocy te becomes smudged and frayed and gradually melts away, releasing the leucocyte into the extravascular space.

Only rarely are interruptions seen in the continuity of either endothelial cell or basement membrane during the passage of leucocytes through them. In most instances, both endothelial cell and basement membrane are continuous and are re-formed behind the leucocyte before either is breached ahead of it. That the process is highly selective is demonstrated by the fact that segmented leucocytes are involved predominantly. The nature of this selectivity was not determined in the present work; it may be related to humoral factors acting on either the leucocyte or the endothelium. Agents which affect the degree or extent of inflammatory exudation may act on the endothelial cell.

The exact processes of margination and emigration describod here may not occur in all species and for all inflammatory stimuli. Preliminary observations suggest that species variations may exist. Under the conditions of the experiment described here, however, the endothelial cell appears to play a very active part in these processes. Full details of this work will be published in the American Journal of Pathology.

\section{J. R. WILLIAMSON}

J. W. Grisham

Department of Pathology,

Washington University School of Medicine, St. Louis, Missouri.

\section{Blood Corticotrophin in Cushing's Syndrome}

Previous work on the level of blood corticotrophin in cases of Cushing's syndrome has been scanty and has not involved a full-scale bioassay of concentrated extracts used at sufficiently high dose-levels. Some of the early work on this subject was reviewed by Loraine ${ }^{1}$ and semiquantitative values for four Cushing's patients have been given by Clayton? 